\title{
Effect of Particle Size and Sintering Temperature on the Formation of Mullite from Kyanite and Aluminum Mixtures
}

\author{
F. R. Barrientos-Hernández $\mathbb{D}^{\mathrm{D}}$, M. Pérez-Labra, A. Lobo-Guerrero, M. Reyes-Pérez, \\ J. C. Juárez-Tapia, J. Hernández-Ávila, E. Cardoso-Legorreta, and J. P. Hernández-Lara
}

Área Académica de Ciencias de la Tierra y Materiales, Universidad Autónoma del Estado de Hidalgo, Carretera Pachuca-Tulancingo km 4.5, C. P. 42184, Mineral de la Reforma, Pachuca, Hidalgo, Mexico

Correspondence should be addressed to F. R. Barrientos-Hernández; profe_3193@uaeh.edu.mx

Received 26 October 2020; Revised 11 February 2021; Accepted 16 February 2021; Published 26 February 2021

Academic Editor: Matjaz Valant

Copyright (c) 2021 F. R. Barrientos-Hernández et al. This is an open access article distributed under the Creative Commons Attribution License, which permits unrestricted use, distribution, and reproduction in any medium, provided the original work is properly cited.

\begin{abstract}
The effect of particle size and sintering temperature of the mixtures of kyanite and metallic aluminum related to the thermal transformation of kyanite into primary mullite and free silica was studied. In addition, the reaction between $\alpha$ - $\mathrm{Al}_{2} \mathrm{O}_{3}$ (in situ produced by aluminum oxidation) and the silica was obtained in cristobalite structure from kyanite to obtain secondary mullite. The kyanite powders were milled by $0.5,3,6$, and 12 hours and then were mixed with aluminum powder, which were previously milled by 3 hours. After that, the powders were characterized by X-ray diffraction technique (XRD), scanning electronic microscopy (SEM), differential thermal analysis (DTA), and thermogravimetric analysis (TGA), and the particle size was determined in a centrifugal analyzer particle size Shimadzu model SA-CP4. The mixed powders were pressed uniaxially into cylindrical samples (compacts), and then sintering was conducted at $1100,1200,1300,1400,1500$, and $1600^{\circ} \mathrm{C}$; these samples were characterized by XRD, SEM, and thermodilatometry analysis (TD); density and open porosity measurements were performed by the Archimedes method. The samples were thermally etched to observe the microstructure, which consisted of mullite equiaxial grains contained in a glassy phase. It was observed that the nonmilled kyanite mineral becomes into mullite plus silica at temperatures between 1400 and $1500^{\circ} \mathrm{C}$. When the particle size was reduced at sizes less than $1 \mu \mathrm{m}$, the transformation temperature was low until $200^{\circ} \mathrm{C}$; the X-ray patterns of the sintered samples at $1400^{\circ} \mathrm{C}$, ground for 6 hours, showed mullite peaks with small reflections of cristobalite and $\alpha-\mathrm{Al}_{2} \mathrm{O}_{3}$, and these samples exhibited high density and low open porosity.
\end{abstract}

\section{Introduction}

Mullite $\left(3 \mathrm{Al}_{2} \mathrm{O}_{3} \cdot 2 \mathrm{SiO}_{2}\right)$ is the only stable silicoaluminate in the binary system of $\mathrm{SiO}_{2}-\mathrm{Al}_{2} \mathrm{O}_{3}$ at atmospheric pressure $[1,2]$ and is a very important refractory material with high melting temperature, high hot strength, excellent thermal shock resistant, and high creep resistance; it is volume stable at very high temperatures, it has a low coefficient of thermal expansion, and it has excellent electrical insulation properties [3, 4]. It has outstanding hot load-bearing properties, and it is resistant to many corrosive environments. Mullite is very low in magnetic iron, which is beneficial in many applications [5]. The finely dispersed, amorphous silica is very reactive and combines easily with sources of alumina to form mullite that is beneficial. Mullite rarely occurs as a mineral in nature. In fact, the word mullite is derived from the Isle of Mull off the west coast of Scotland, where the only naturally occurring deposits of mullite have ever been found [6-8]. Kyanite is an anhydrous aluminosilicate, with crystalline structure triclinic, it belongs to the $\mathrm{Al}_{2} \mathrm{O}_{3}-\mathrm{SiO}_{2}$ system, and its chemical formula is $\mathrm{Al}_{2} \mathrm{O}_{3} \cdot \mathrm{SiO}_{2}$; its decomposing at high temperatures produces mullite $\left(3 \mathrm{Al}_{2} \mathrm{O}_{3} \cdot 2 \mathrm{SiO}_{2}\right)$ and free silica $\left(\mathrm{SiO}_{2}\right)$. The mullitization process accompanies $16-18 \mathrm{vol} \%$ expansion, making it be widely used as expanding agent in the refractory field [9]. Decomposition occurs according to the following reaction: 


$$
3\left(\mathrm{Al}_{2} \mathrm{O}_{3} \cdot \mathrm{SiO}_{2}\right) \stackrel{\Delta}{\longrightarrow} 3 \mathrm{Al}_{2} \mathrm{O}_{3} \cdot 2 \mathrm{SiO}_{2}+\mathrm{SiO}_{2}
$$

kyanite primary mullite + cristobalite

Sainz et al. [10] showed that the formation of mullite from kyanite is carried out by means of thermal transformation; the kyanite decomposes into mullite plus silica due to the induced heat. During the decomposition, they found different stages of transformation and formation of a liquid. The first stage was at $1320^{\circ} \mathrm{C}$, which corresponds to the beginning of the transformation of the kyanite; the second stage was located between 1320 and $1420^{\circ} \mathrm{C}$, associating with the progress of the reaction allowing a complete transformation to $1420^{\circ} \mathrm{C}$. Raghdi et al. [11] synthesized mullitezirconia composites prepared from halloysite reaction with boehmite and zirconia. They reported the phase transformations that ended at $1550^{\circ} \mathrm{C}$ with the formation of monolithic mullite in halloysite-boehmite mixture and mullite-zirconia composites in halloysite-boehmite-zirconia mixture. Goski and Caley [12] investigated the reaction sintering of kyanite and alumina to form mullite composites, and the resulting $78 \%-22 \%$ mullite material formed a finegrained structure $(1 \mu \mathrm{m})$ with $14 \%$ decrease in shrinkage and $11 \%$ reduction in linear expansion coefficient. Chargui et al. [13] prepared mullite from natural kaolin and aluminum slag; they studied the structural transformations of kaolinaluminum slag mixtures during heating. The amount of formed mullite increases with the firing temperature; at $1500^{\circ} \mathrm{C}$, the mullitization of the mixture is almost complete. The morphology of the formed mullite is bimodal (primary and secondary phases). The primary mullite, formed from processing of kaolin by the gradual collapse of metakaolin from $990^{\circ} \mathrm{C}$, has a shape of elongated crystals. On the other hand, the secondary mullite formed by solution-precipitation from the glass phase in the presence of alumina particles has a shape of acicular grains. Guo and Li [14] fabricated mullite ceramics with different crystal shapes of mullite by in situ reaction with middle-grade kyanite as raw material, $\mathrm{Al}(\mathrm{OH})_{3}$,
$\gamma-\mathrm{Al}_{2} \mathrm{O}_{3}, \rho-\mathrm{Al}_{2} \mathrm{O}_{3}$, and $\alpha-\mathrm{Al}_{2} \mathrm{O}_{3}$ as alumina sources. Results showed that mullite in the sample with $\mathrm{Al}(\mathrm{OH})_{3}$ mainly showed acicular morphology, with a successive slowdown in reactivities of $\mathrm{Al}(\mathrm{OH})_{3}, \gamma-\mathrm{Al}_{2} \mathrm{O}_{3}, \rho-\mathrm{Al}_{2} \mathrm{O}_{3}$, and $\alpha-\mathrm{Al}_{2} \mathrm{O}_{3}$, the amount and aspect ratio of mullite were reduced, and its growth mechanism gradually transforms into two-dimensional nucleation. Acicular mullite not only reinforced samples but also made effective pore sizes smaller, which allowed the sample with $\mathrm{Al}(\mathrm{OH})_{3}$ to present low bulk density, high apparent porosity and linear changes, small average pore size, and good mechanical strength. Sánchez-Soto et al. [15] utilized kaolin waste, sericite clay containing kaolinite, and industrial kaolin with addition of alumina in a wet medium to synthesize mullite (72 wt $\% \mathrm{Al}_{2} \mathrm{O}_{3}$ and $28 \mathrm{wt} \% \mathrm{SiO}_{2}$ ). They found by sintering at $1500-1600^{\circ} \mathrm{C}$ for, at least, $30 \mathrm{~min}$, and the reaction sintering between $\alpha$-alumina and silica originated from thermal decomposed kaolinite in the samples produced mullite. According to XRD results, it evidenced the disappearance of residual crystalline phases, mainly quartz and cristobalite, with relicts of $\alpha$-alumina in a single case. The thermal phase evolution was affected by the presence of impurities in the mixtures. These impurities produce, in fact, the formation of a glassy phase or partial vitrification in some areas as deduced by SEM-EDS, giving rise to a better sintering which allow the sample to reach a $74 \%$ of total densification. A variety of preparation methods are used to synthetize mullite from various materials, such as alumina-silica minerals, hydroxides, sols, silicon alkoxide, and aluminum alkoxide $[16,17]$. In the present work, the reaction sintering of kyanite + aluminum mixtures has been used in the synthesis of the mullite samples studied. The processing route employed can be explained according to the following reactions [9]:

$$
\begin{aligned}
& 3\left(\mathrm{Al}_{2} \mathrm{O}_{3} \cdot \mathrm{SiO}_{2}\right) \stackrel{\Delta}{\longrightarrow} 3 \mathrm{Al}_{2} \mathrm{O}_{3} \cdot 2 \mathrm{SiO}_{2}+\left(\mathrm{SiO}_{2}\right) \text { expelled } \\
& 2 \mathrm{Al}(\text { metal })+3 / 2\left(\mathrm{O}_{2}\right) \text { air } \stackrel{\Delta}{\longrightarrow}\left(\mathrm{Al}_{2} \mathrm{O}_{3}\right) \text { in situ } \\
& 3\left(\mathrm{Al}_{2} \mathrm{O}_{3}\right) \text { in situ }+2\left(\mathrm{SiO}_{2}\right) \text { expelled } \stackrel{\Delta}{\longrightarrow} 3 \mathrm{Al}_{2} \mathrm{O}_{3} \cdot 2 \mathrm{SiO}_{2} \\
& \text { secondary mullite }
\end{aligned}
$$

Reaction sintering is an adaptation of the reaction bonding aluminum oxide developed by Claussen et al. [18] who found that the reaction bonded is an oxidation-based process, which begins with a compact of aluminum and alumina. During heating in air, the Al particles are oxidized in the solid state having a volume expansion $\approx 28 \%$, which can compensate for the shrinkage by sintering. The oxidation of the aluminum particles represents the key to this new technology for obtaining $\mathrm{Al}_{2} \mathrm{O}_{3}$-based composites. The characteristics of these composites are as follows: low sintering shrinkage and high resistance. The low shrinkage results from a partial compensation for sintering shrinkage by an expansion associated with oxidation. The high resistance is due to the fine grain size $(<1 \mu \mathrm{m})$ which develops during the reaction bonding process. Reaction sintering has been shown to favour the absence of sintering aids which can 
allow for improved strength and final density at lower firing temperatures. The principle advantage of reaction sintering is foreseen as the in situ development of multiphase composites with a fine, uniform microstructure achieved using economical reactants $[19,20]$.

\section{Materials and Methods}

For this work, the starting materials were kyanite ore $\left(\mathrm{Al}_{2} \mathrm{O}_{3} \cdot \mathrm{SiO}_{2}\right)$ from the Kyanite Mining Corporation located in Dillwyn, Virginia, USA, with an average particle size of 35 mesh $(417 \mu \mathrm{m})$, and aluminum powder, Alcoa Atomized Aluminum Powder, $20 \mu \mathrm{m}$. The phase identification was performed by X-ray diffractometry (XRD, Model Equinox 2000, Inel, Artenay, France) with $\mathrm{Cu} \mathrm{K} \alpha 1$ $(1.5406 \AA)$ radiation, operating at $30 \mathrm{~mA}$ and $20 \mathrm{kV}$. The morphology and microstructure were observed in a scanning electron microscopy (SEM, Model 6300, JEOL, Tokyo, Japan) with an accelerating voltage of $15 \mathrm{kV}$. The particle size was determined in a centrifugal analyzer particle size Shimadzu model SA-CP4; the specific surface area was performed by the nitrogen adsorption method (BET). The milling of the kyanite and metallic aluminum was carried out separately in a vertical mill attritor Szegvari (Union Process, USA), with a cylindrical stainless steel container capacity of $3.785 \mathrm{~L}$ in air, the grinding media were steels balls of $5 \mathrm{~mm}$ diameter, and milling time was $0.5,3,6$, and 12 hours at $400 \mathrm{rpm}$. The aluminum was milled for 3 hours in wet with $100 \mathrm{ml}$ of isopropanol as a control agent; then, kyanite ground at different times was mixed for $0.5 \mathrm{~h}$, in order to homogenize the mixture. For the preparation of mixtures of aluminum kyanite, $15.73 \%$ $\mathrm{Al}$ and $84.27 \%$ kyanite were weighed to form a mullite $3: 2$ $\left(3 \mathrm{Al}_{2} \mathrm{O}_{3} \cdot 2 \mathrm{SiO}_{2}\right)$ according to equation (2). The powder mixture was die-pressed uniaxially in a hydraulic press Stroud Daniels at $180 \mathrm{MPa}$ into disks of $10 \mathrm{~mm} \times 6 \mathrm{~mm}$, and it was fired in a muffle furnace Thermolyne brand, model 46200, with 8 heating elements of SuperKanthal 33 in air at a heating rate of $1^{\circ} \mathrm{C} / \mathrm{min}$ up to $950^{\circ} \mathrm{C}$, followed by $10^{\circ} \mathrm{C} / \mathrm{min}$ heating to different temperatures $(1100,1200$, $1300,1400,1500$, and $1600^{\circ} \mathrm{C}$ ). The thermal decomposition, weight, and dimensional changes were studied by TG/DTA (Setaram Model Setsys Evolution, Caluire, France) under an air atmosphere at a constant heating rate of $10^{\circ} \mathrm{C} / \mathrm{min}$. Bulk density of fired samples was determined by measuring of its mass and volume (the Archimedes method using distilled water), and porosity values were calculated from its bulk density and the theoretical density of mullite, using the following equation [21]:

$$
V_{P}=\left(1-\frac{\rho_{b}}{\rho_{t}}\right) \times 100,
$$

where $\rho_{\mathrm{b}}\left(\mathrm{g} / \mathrm{cm}^{3}\right)$ is the bulk density of a sample and $\rho_{\mathrm{t}}$ $\left(3.16 \mathrm{~g} / \mathrm{cm}^{3}\right)$ is the theoretical density of mullite. The chemical composition of raw materials was determined by atomic absorption spectroscopy (AAS, Model 2380, Perkin Elmer, Waltham, Massachusetts). For practical purposes, the letter $\mathrm{K}$ is used to identify the unmixed kyanite and $\mathrm{KA}$ for the kyanite-aluminum mixtures followed by the milling time.

\section{Results and Discussion}

3.1. Sample Preparation. Figure 1 shows the diffractogram of the original kyanite, which is dominated by a very large peak at $26.6^{\circ} 2$ theta, the (200) planes, while the relative intensities of the remaining reflections are smaller as reported in the JCPDS card no. 11-0046. In addition, small reflections of quartz and muscovite were identified.

The chemical composition of raw materials is shown in Table 1 , mullite $(3: 2)$ has a theoretical $\mathrm{Al}_{2} \mathrm{O}_{3} / \mathrm{SiO}_{2}$ ratio of 2.54 , this value is below for all mixtures, and this difference is possibly due to aluminum losses during grinding. Due to the wear of the grinding media (steel ball), there was contamination of $\mathrm{Fe}_{2} \mathrm{O}_{3}$ (until $4.8 \%$ weight for KA12) in the kyanitealuminum powders, so the mixtures were leached with a concentrated solution of hot $\mathrm{HCl}$. As we can see, this method was effective and reduced the amount of $\mathrm{Fe}_{2} \mathrm{O}_{3}$ to values of 0.185 for the same sample.

Figure 2 shows the micrographs of raw materials; the morphology and the size of the precursor powders were determined by scanning electron microscopy, the kyanite powders 2(a) are prismatic, elongated, tabular crystals with a size up to $400 \mu \mathrm{m}$ long, and the aluminum powders have a cylindrical shape with a size $\approx 20 \mu \mathrm{m}$.

The micrographs of mixed powders of kyanite-aluminum are observed in Figure 3; the unmilled mixture 3(a) is formed by elongated crystals of kyanite of approximately $300 \mu \mathrm{m}$ in length covered by aluminum particles; after $0.5 \mathrm{~h}$ of grinding 3 (b), the original morphology of the kyanite is no longer visible, and the particles showed average sizes of $6 \mu \mathrm{m}$. The powders milled for $3 \mathrm{~h} \mathrm{3}$ (c) consisted of elongated particles of up to $3 \mu \mathrm{m}$ and others of smaller size, and the powders obtained during the grinding of $6 \mathrm{~h} 3(\mathrm{~d})$ showed particles smaller than $1 \mu \mathrm{m}$ and agglomerates of finer particles. Finally,

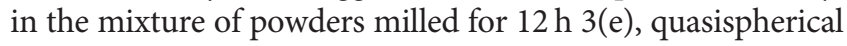
particles with sizes smaller than $1 \mu \mathrm{m}$ were observed; it should be noted that aluminum was observed as irregular shaped particles with average sizes of 3 to $1 \mu \mathrm{m}$, and this morphology is due to the ductile nature of aluminum as it tends to be rolled at the time of grinding. The particle size distribution of the milled kyanite at different times is observed in Figure 4; the powders of the K0.5 sample exhibited a bimodal size distribution, with $60 \%$ of the particles in an interval of coarse size of 4 to $40 \mu \mathrm{m}$, and $40 \%$ of the particles in a fine range of 0.3 to $1.5 \mu \mathrm{m}$. The samples $\mathrm{K} 3, \mathrm{~K} 6$, and $\mathrm{K} 12$ were obtained with average sizes $\left(d_{50}\right)$ of $0.52,0.38$, and $0.16 \mu \mathrm{m}$, respectively. The specific surface area of the kyanite and the mixtures of kyanite-aluminum are observed in Table 2. For kyanite-aluminum mixtures, it can be noted that the increase in grinding time generated an increase in the specific surface area from $8.4 \mathrm{~m}^{2} \cdot \mathrm{g}^{-1}$ at $0.5 \mathrm{~h}$ of milling time to $42.36 \mathrm{~m}^{2} \cdot \mathrm{g}^{-1}$ at $12 \mathrm{~h}$ of milling.

3.2. X-Ray Diffraction. The X-ray diffraction patterns for the raw kyanite and kyanite-aluminum mixtures are shown in 


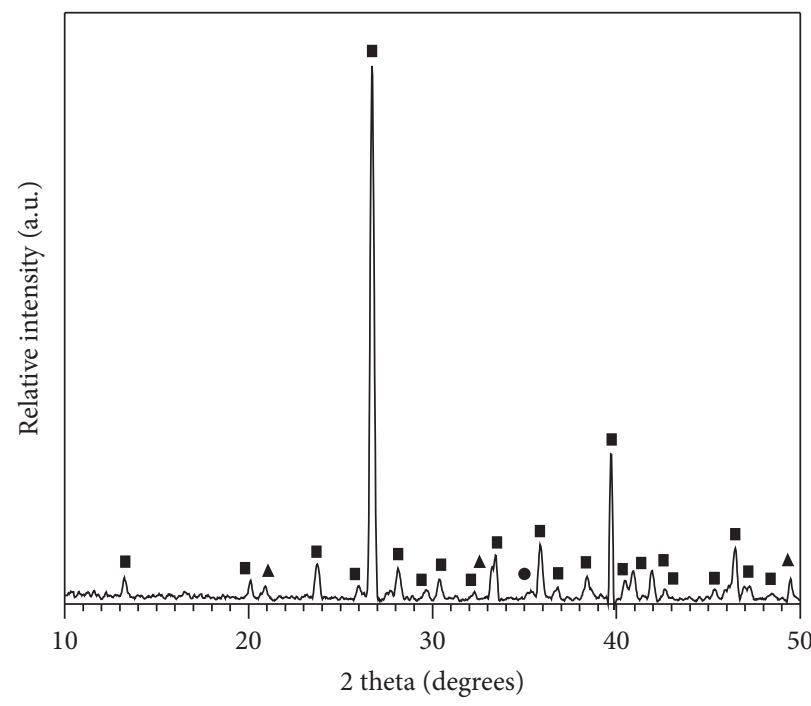

- Kyanite

\ Quartz

- Muscovite

FIGURE 1: X-ray diffraction pattern of kyanite raw.

TABLe 1: Chemical composition of kyanite raw and kyanite-aluminum mix (\%).

\begin{tabular}{|c|c|c|c|c|c|c|c|c|c|}
\hline \multirow{2}{*}{ Oxides } & \multicolumn{4}{|c|}{ Kyanite (K) } & \multicolumn{5}{|c|}{ Kyanite + aluminum (KA) } \\
\hline & K0 & K3 & K6 & K12 & KA0 & KA0.5 & KA3 & KA6 & KA12 \\
\hline $\mathrm{Al}_{2} \mathrm{O}_{3}$ & 58.30 & 58.9 & 59.1 & 59.5 & 66.9 & 67.8 & 68.3 & 68.5 & 68.8 \\
\hline $\mathrm{SiO}_{2}$ & 38.60 & 38.01 & 38.15 & 37.95 & 30.98 & 29.50 & 29.59 & 29.67 & 28.15 \\
\hline $\mathrm{Fe}_{2} \mathrm{O}_{3}$ & 0.40 & 0.185 & 0.217 & 0.223 & 0.126 & 0.165 & 0.175 & 0.178 & 0.185 \\
\hline $\mathrm{TiO}_{2}$ & 1.78 & 1.83 & 1.33 & 1.17 & 1.00 & 0.84 & 0.82 & 0.85 & 0.83 \\
\hline $\mathrm{Na}_{2} \mathrm{O}$ & 0.82 & 0.80 & 0.85 & 0.81 & 0.63 & 0.65 & 0.632 & 0.67 & 0.68 \\
\hline $\mathrm{K}_{2} \mathrm{O}$ & 0.10 & 0.15 & 0.15 & 0.18 & 0.078 & 0.086 & 0.090 & 0.089 & 0.090 \\
\hline $\mathrm{Al}_{2} \mathrm{O}_{3} / \mathrm{SiO}_{2}$ & 1.51 & 1.55 & 1.55 & 1.57 & 2.16 & 2.30 & 2.31 & 2.31 & 2.44 \\
\hline
\end{tabular}

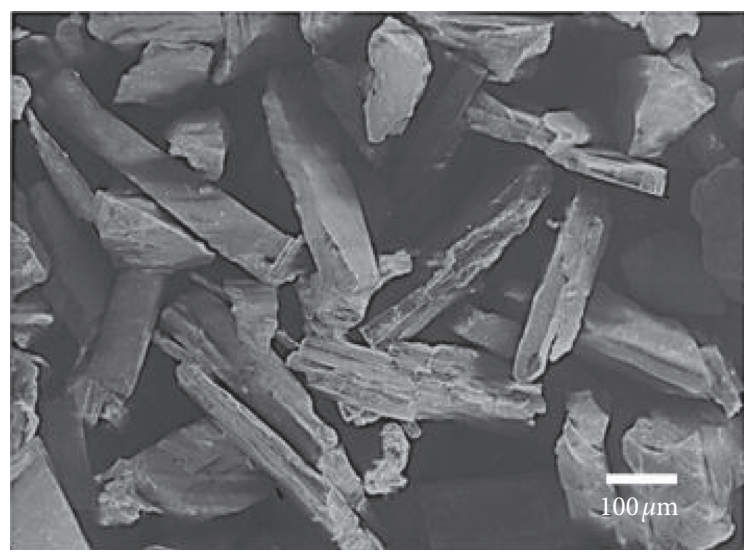

(a)

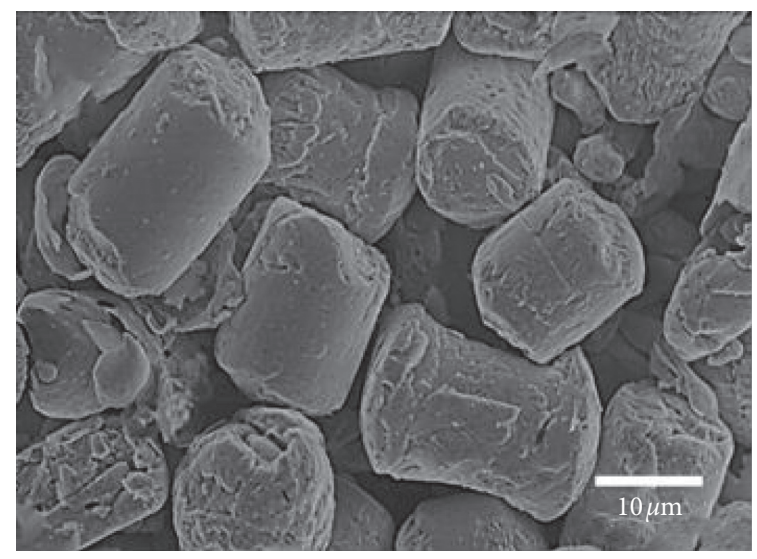

(b)

Figure 2: SEM images of raw kyanite (a) and aluminum powder (b).

Figure 5; it can be observed that no reaction occurred during the milling 5 (a) as peak patterns of milled samples are basically overlapping peaks in the XRD patterns of the unmilled samples.
Although peaks in the diffractograms of the samples milled 5(b) are smaller and wider because of the decrease in crystallite size and possible microstrain contained in the powder particles, in addition, aluminum peaks in $38.5^{\circ}$ and 


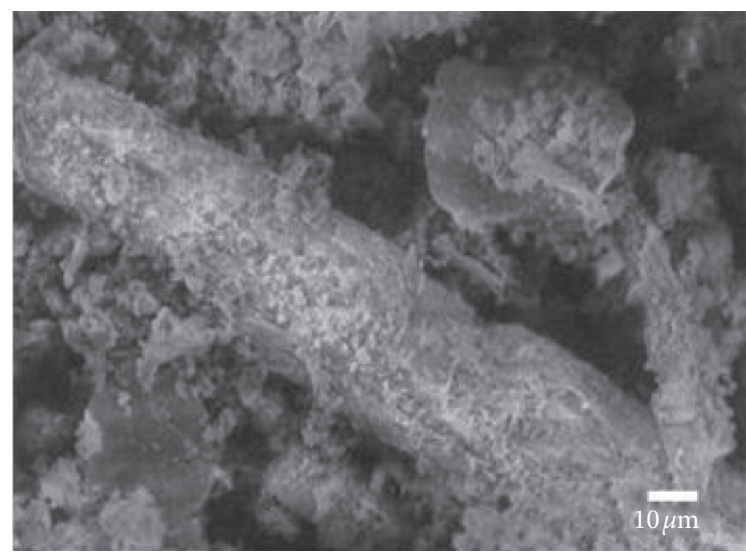

(a)

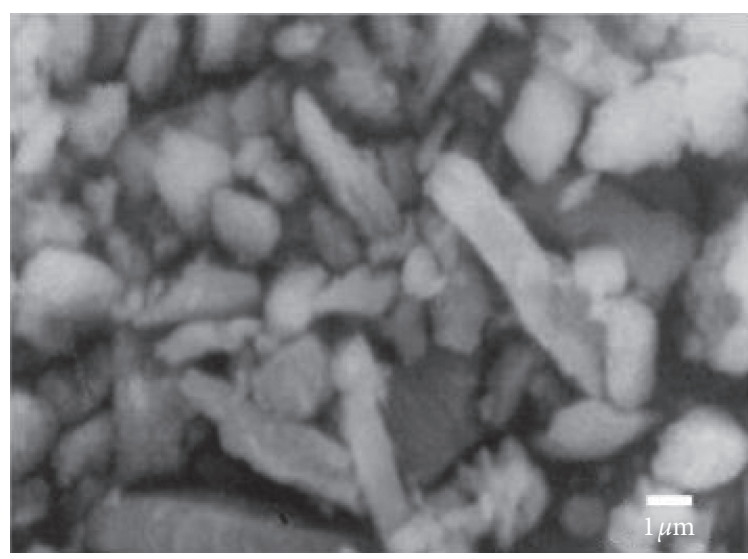

(c)

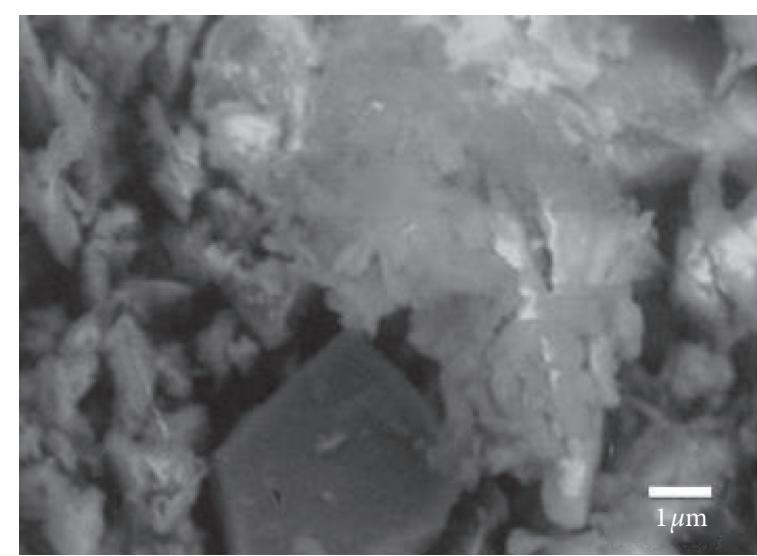

(b)

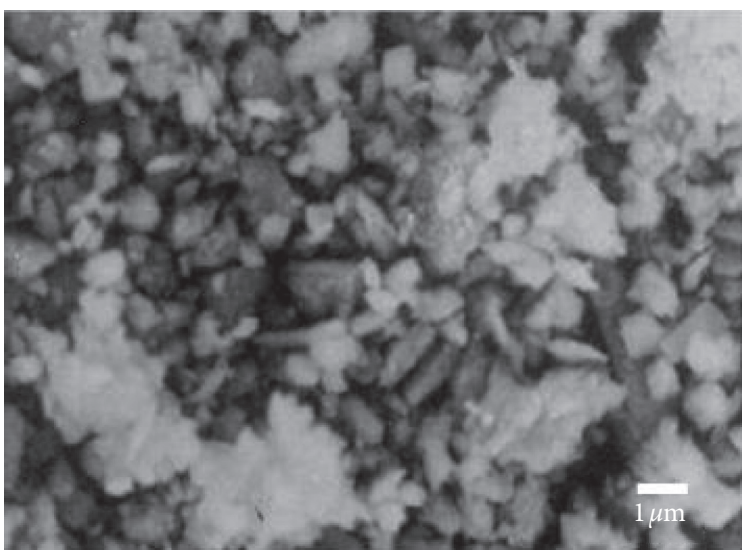

(d)

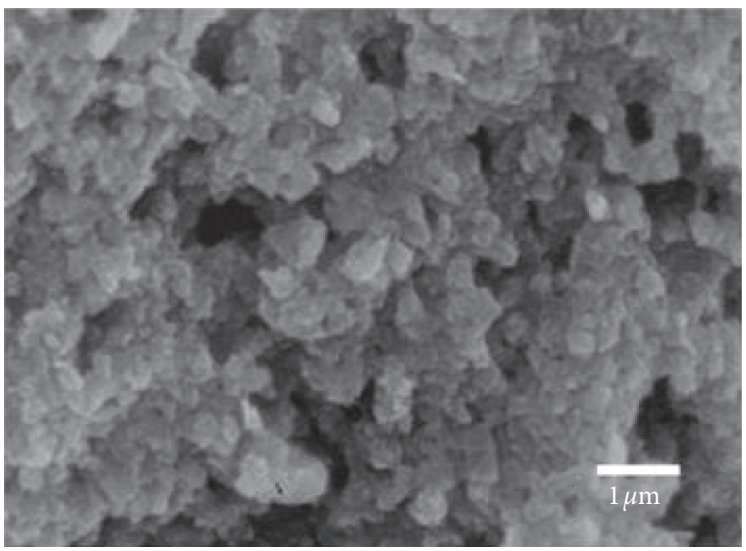

(e)

Figure 3: Micrographs of kyanite-aluminum mixtures milled at different times: (a) KA0 h, (b) KA0.5 h, (c) KA3 h, (d) KA6 h, and (e) KA12 h.

$44.74^{\circ} 2$ theta were observed [15]. The transformation of kyanite into mullite is closely related to the size of kyanite powders and sintering temperature [22]. Figure 6 shows the XRD patterns of the phase evolution of the mixture of kyanite and aluminum powders milled at different times and sintered in a range of $1100-1600^{\circ} \mathrm{C}$. In Figure 6(a), we can see the samples unmilled $(\mathrm{KA} 0 \mathrm{~h})$ and sintered at $1100^{\circ} \mathrm{C}$; in this sample, the major phase is kyanite $(k)$ and $\alpha-\mathrm{Al}_{2} \mathrm{O}_{3}$ is obtained by the aluminum oxidation [23]. In the range of $1200-1500^{\circ} \mathrm{C}$, it is observed that the reflection intensity of kyanite decreased, while the expelled silica (cristobalite-CR) and formed primary mullite were increased due to the sintering temperature. Finally, mullite without any traces of crystalline silica was formed after sintering at $1600^{\circ} \mathrm{C}$. Cristobalite is a silica polymorph in ceramic materials, as it can crystallize in $\mathrm{SiO}_{2}$-rich systems during high-temperature processes. The formation of cristobalite was increased at temperature $\geq 1200^{\circ} \mathrm{C}$; at this temperature, the peak of 


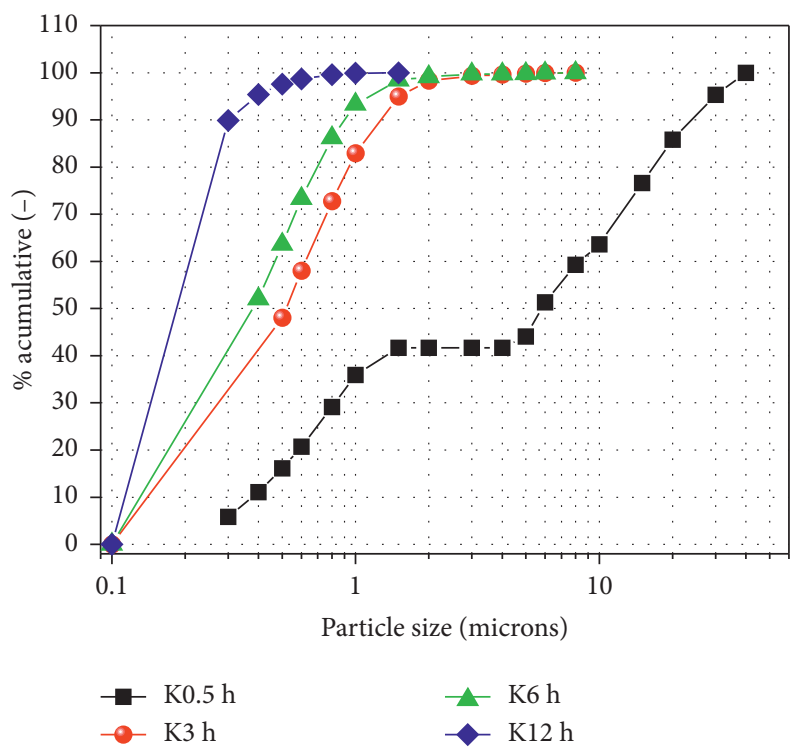

FIgUre 4: Particle size distribution of ground kyanite at different times.

TABle 2: Average size and specific surface area of kyanite raw and kyanite-aluminum mix.

\begin{tabular}{lccc}
\hline $\begin{array}{l}\text { Milling time } \\
(\mathrm{h})\end{array}$ & $\begin{array}{c}\text { Average size of kyanite } \\
(\mu \mathrm{m})\end{array}$ & $\begin{array}{c}\text { Specific surface area of kyanite } \\
\left(\mathrm{m}^{2} \cdot \mathrm{g}^{-1}\right)\end{array}$ & $\begin{array}{c}\text { Specific surface area of kyanite-aluminum mixtures } \\
\left(\mathrm{m}^{2} \cdot \mathrm{g}^{-1}\right)\end{array}$ \\
\hline 0.5 & 5.82 & 8.51 & 8.40 \\
3 & 0.52 & 21.35 & 20.19 \\
6 & 0.38 & 32.1 & 39.03 \\
12 & 0.16 & 40.4 & 42.36 \\
\hline
\end{tabular}

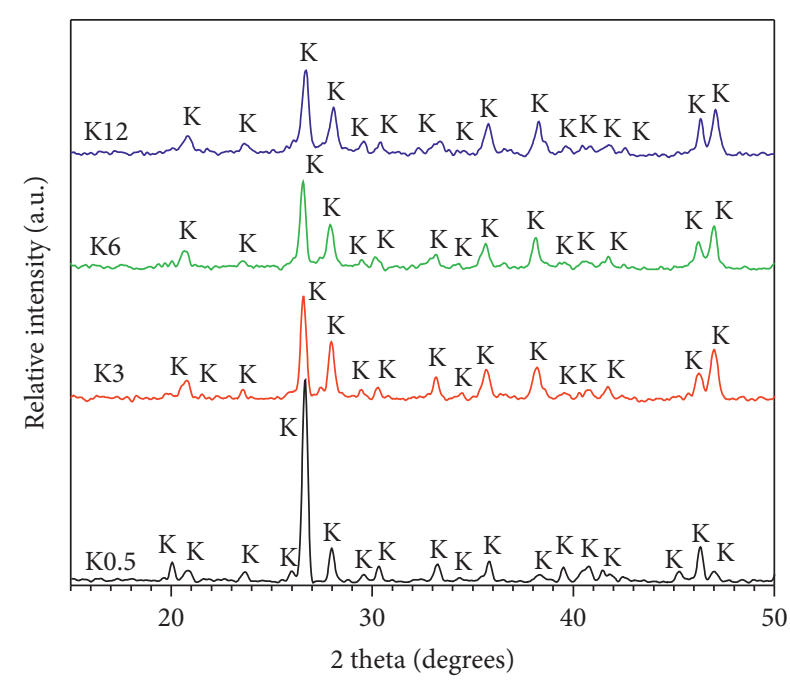

(a)

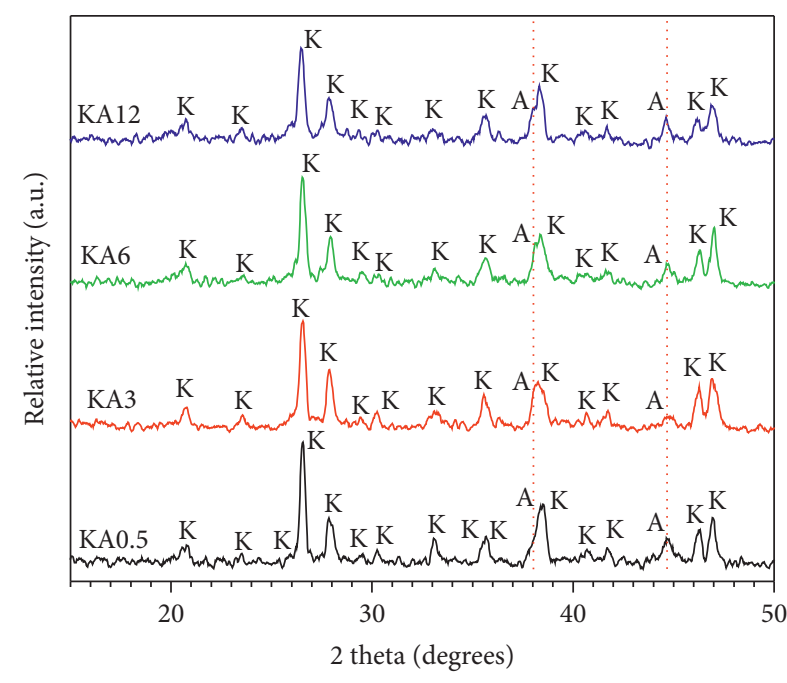

(b)

FIGURE 5: XRD patterns of the raw kyanite (a) and kyanite-aluminum metal mixtures (b) milling at different times. $K=$ kyanite; $A=$ aluminum.

cristobalite is barely noticeable, but a notable increase occurs in the samples KA6 h and KA12 h. Sahraoui et al. [24] investigated the effects of mechanical activation on the sintering of mullite produced from kaolin and aluminum metal powders. The results showed the formation of silicon, quartz, and small amount of nacrite after $40 \mathrm{~h}$ of milling at room temperature. All mixture powders milled for different time showed the formation of several alumina transitions during heat treatment. The formation of alumina transitions, $\alpha$-alumina, cristobalite crystallization, and mullite (primary and secondary) formation was affected by ball milling time. The mixture of kaolin and aluminum milled for $40 \mathrm{~h}$ shows 


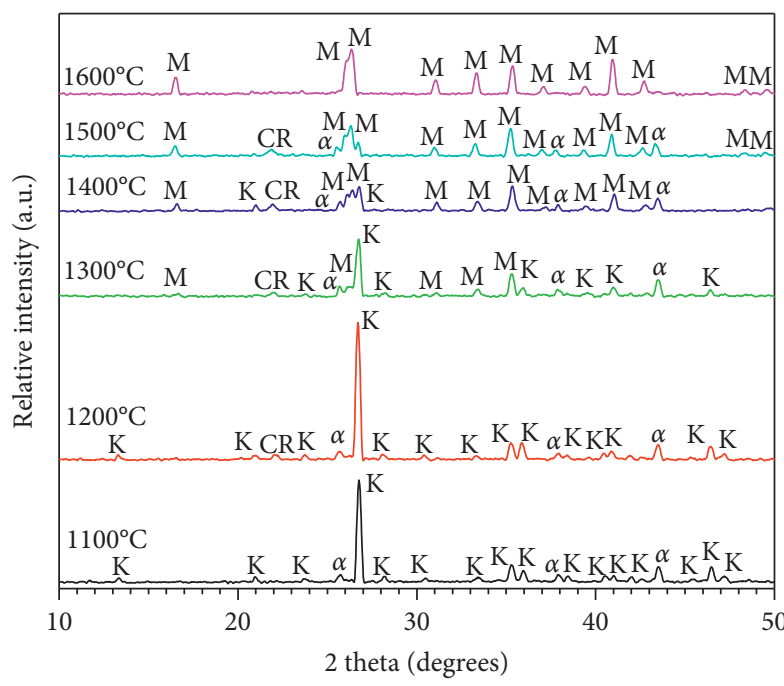

(a)

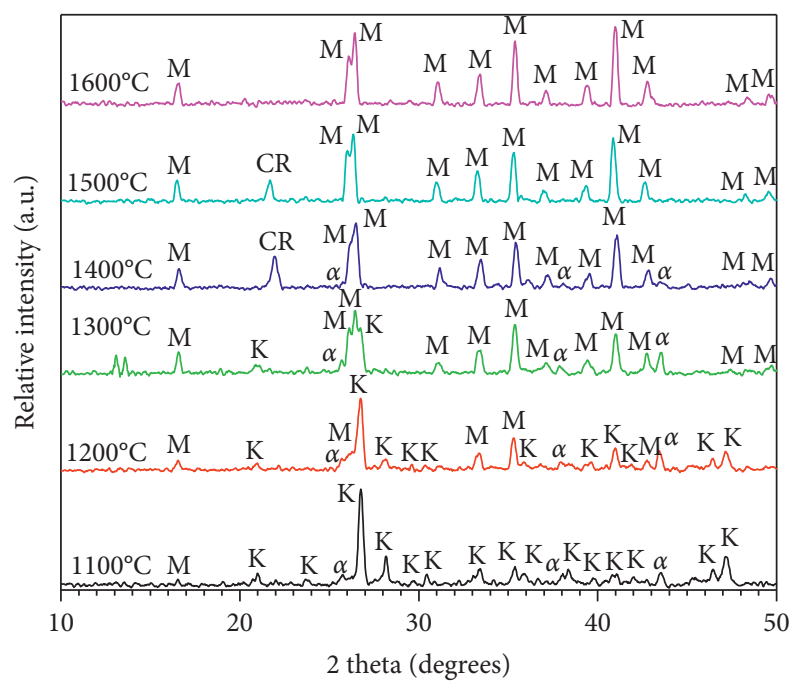

(c)

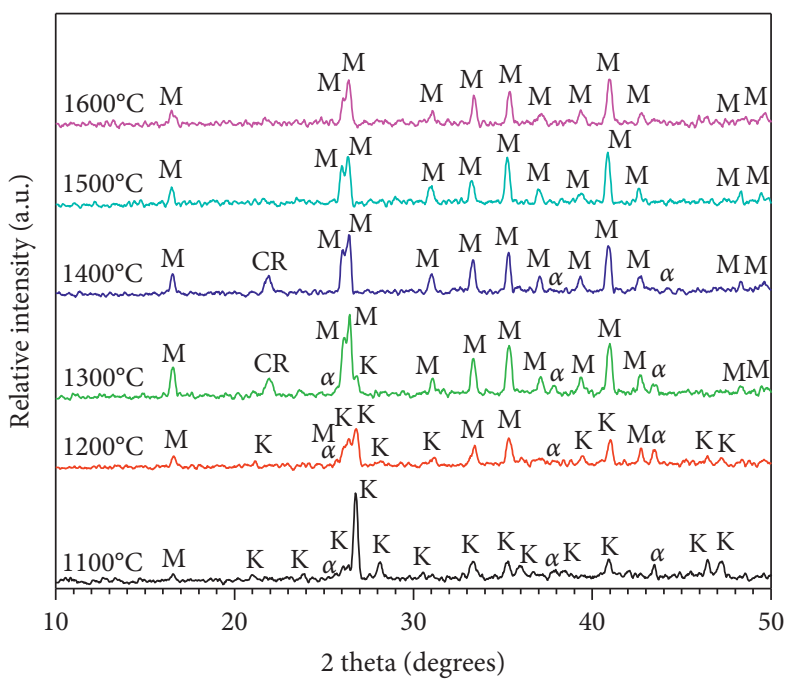

(b)

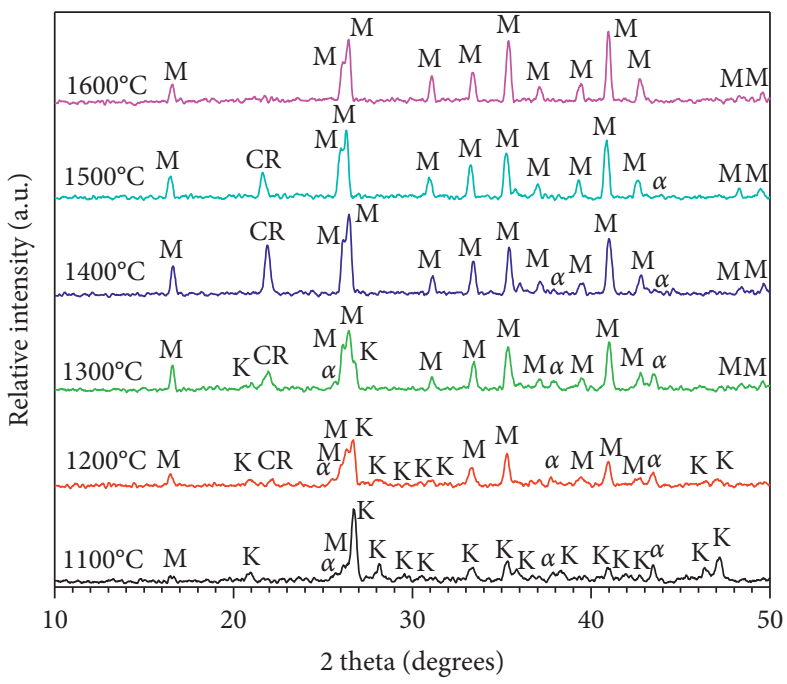

(d)

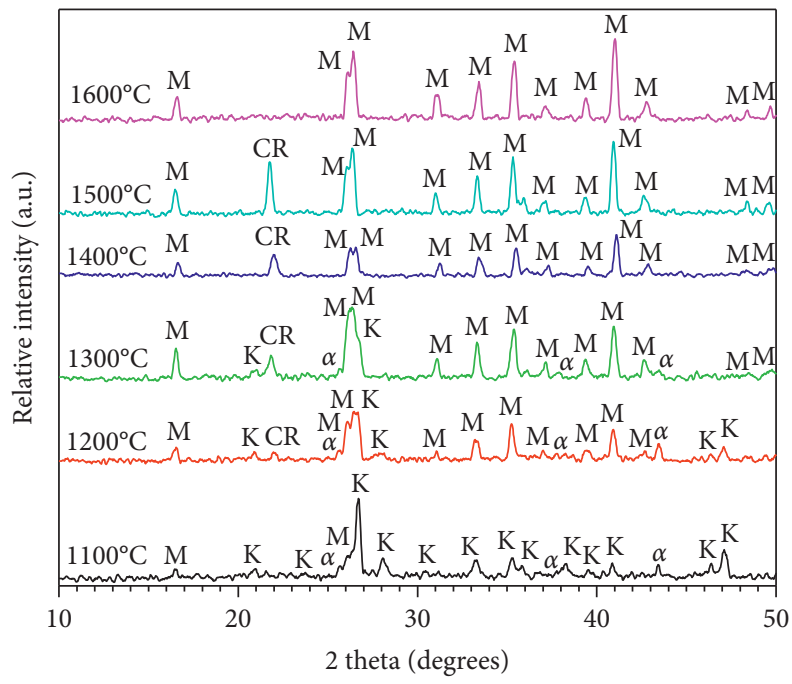

(e)

Figure 6: XRD patterns of mixture of kyanite-aluminum powder milled at (a) KA0 h, (b) KA0.5 h, (c) KA3 h, (d) KA6 h, and (e) KA12 h at different sintering temperatures. $K=$ kyanite, $A=$ aluminum, $M=$ mullite, $\mathrm{CR}=$ cristobalite, and $\alpha=\alpha-\mathrm{Al}_{2} \mathrm{O}_{3}$. 
the formation of kyanite $\left(\mathrm{Al}_{2} \mathrm{SiO}_{5}\right)$ at $1300^{\circ} \mathrm{C}$, and the mechanical treatment enhances the formation and sintering of mullite. After $0.5 \mathrm{~h}$ of milling, Figure 6(b) shows the XRD patterns of the mixture sintering at various temperatures; at $1100-1200^{\circ} \mathrm{C}$, the primary mullite phase started to form from the decomposition of kyanite. The majority phase is still kyanite with minor amounts of $\alpha-\mathrm{Al}_{2} \mathrm{O}_{3}$. In the range of $1300-1400^{\circ} \mathrm{C}$, the cristobalite phase started and the peaks of kyanite were not observed and noticeably increased the reflections of mullite. The behavior at 1500 and $1600^{\circ} \mathrm{C}$ is similar, so the mullitization reaction finished (from $1500^{\circ} \mathrm{C}$ ) and could be observed only the characteristic peaks of mullite. Sule et al. [25] investigated the effect of temperature on mullite synthesis from attrition-milled pyrophyllite and $\alpha$-alumina by spark plasma sintering at temperatures ranging from $1400^{\circ} \mathrm{C}$ to $1700^{\circ} \mathrm{C}$, with this increase in sintering temperature, and the results showed a phase of mullite and a minority phase of alumina. They also determined that the intensities of alumina peaks gradually decreased with increasing sintering temperature. Figure 6(c) shows the XDR spectra of the powders milled for $3 \mathrm{~h}$; in the sample heated at $1000^{\circ} \mathrm{C}$, it could be determined that the major phase was kyanite and minor ones were mullite and $\alpha-\mathrm{Al}_{2} \mathrm{O}_{3}$. In the range of $1200-1300^{\circ} \mathrm{C}$, the intensities of the kyanite reflections were decreased markedly and the mullite peaks increased. At $1400-1500^{\circ} \mathrm{C}$, cristobalite started to derive from the decomposition of kyanite; at $1600^{\circ} \mathrm{C}$, the mullitization reaction ends, and secondary mullite was formed through the interaction of $\alpha-\mathrm{Al}_{2} \mathrm{O}_{3}$ and $\mathrm{SiO}_{2}$ (cristobalite). Figures $6(\mathrm{~d})$ and $6(\mathrm{e})$ show the XRD patterns of the samples milled at $6 \mathrm{~h}$ and $12 \mathrm{~h}$, respectively; the behavior is very similar, the decomposition started at $1200^{\circ} \mathrm{C}$ decreasing the kyanite peaks completely to temperature $>1300^{\circ} \mathrm{C}$, the cristobalite peak disappeared to $1600^{\circ} \mathrm{C}$, and only the characteristic reflections of mullite were observed. The above behavior suggests that the reaction of decomposition accelerated with increasing temperature and decreasing particle size $[24,26]$. Similar conclusion was drawn by Khattab et al. [27], where XRD patterns showed that by increasing the sintering temperature up to $1350^{\circ} \mathrm{C}$, the peak intensity of cristobalite and quartz has been decreased with remarkable increase in the peak intensity of mullite and cordierite. Such decrease in peak intensity of cristobalite and quartz may be attributed to their reaction with $\mathrm{MgO}$ and $\mathrm{Al}_{2} \mathrm{O}_{3}$ forming cordierite and mullite.

3.3. Thermogravimetric Analysis (TGA). Thermogravimetric behavior for the samples KA0 h and KA12 $\mathrm{h}$ is presented in Figures 7(a) and 7(b), respectively; in Figure 7(a), the initial mass reduction of $2.9 \%$ observed was associated with the evaporation of organic species that were absorbed during milling. Aluminum oxidation occurs in two well-defined stages; the first stage was observed in the range of $380-658^{\circ} \mathrm{C}$ (the solid-state oxidation of aluminum powder) with a weight gain of $7.2 \%$. Later, an increment was identified in a weight of $2.7 \%$ in the second stage $\left(658-840^{\circ} \mathrm{C}\right)$ due to oxidation of aluminum in the liquid state. At $1420^{\circ} \mathrm{C}$, the mullitization reaction was complete, this temperature agrees with the XRD results (Figure 6(a)), and when above $1400^{\circ} \mathrm{C}$, the presence of kyanite is no longer observed.

The behavior of the KA12 sample (Figure 7(b)) was similar; firstly, initial weight loss of $7.5 \%$ was greater than the sample KA0 h, since when milled for 12 hours, it absorbed more amount of organic species, since isopropyl alcohol was used as a control agent. The oxidation of aluminum in the solid state (first stage) was observed in the range of $450-658^{\circ} \mathrm{C}$, with a weight gain of $3.2 \%$; finally, a rate of oxidation reaction is reduced from 658 until $850^{\circ} \mathrm{C}$. The decomposition temperature of kyanite is reduced by approximately $100^{\circ} \mathrm{C}$ with respect to the unground sample, since in this case, this happened at approximately $1315^{\circ} \mathrm{C}$. This decrease is due to presumably because the very fine particle sizes experience a change in the kinetics of the decomposition reactions. Attrition-milling also produces much more reactive rejected silica that readily combines with aluminum oxide obtained in situ from aluminum metal additions to produce a phase-pure mullite [24].

3.4. Thermodilatometry (TD). The dilatometric behavior curves of the samples KA0 h and KA12 h are presented in Figures 8(a) and 8(b), respectively. In Figure 8(a), it can be seen that in the range of $330-830^{\circ} \mathrm{C}$, an expansion of approximately $2.3 \%$ corresponds to the oxidation of aluminum. A slight expansion can be noticed at $660^{\circ} \mathrm{C}$ due to the melting of the aluminum. The reaction of kyanite decomposition occurs between 1325 and $1460^{\circ} \mathrm{C}$ with an expansion of $8.9 \%$, followed by $5.6 \%$ shrinkage caused by sintering the sample. Figure 8 (b) shows the dilatometry curve of the mixture $\mathrm{KA} 12 \mathrm{~h}$; the curve shows in $370-840^{\circ} \mathrm{C}$ a slight expansion caused by the oxidation of the aluminum. The next observed change was a contraction (approximately 6\%) starting at approximately $1030^{\circ} \mathrm{C}$, which was followed by the kyanite transformation between 1265 and $1310^{\circ} \mathrm{C}$, with a slight expansion of $0.5 \%$. Then, a strong sintering shrinkage of $15.5 \%$ begins, and this section of the curve shows a deflection around $1485^{\circ} \mathrm{C}$, which could indicate that the sample entered the final stage of sintering.

In addition to this change, at $1410^{\circ} \mathrm{C}$, the curve showed a change in slope that could be associated with the reaction between the silica released by kyanite and the alumina that was formed by the oxidation of aluminum, whose product would be secondary mullite. Decomposition is accompanied by a characteristic volume expansion which can be as large as $16-18 \%$, since kyanite is denser than mullite, $3.5-3.7 \mathrm{~g} / \mathrm{cm}^{3}$ and $3.16 \mathrm{~g} / \mathrm{cm}^{3}$, respectively. The attrition-milling accelerates the decomposition of kyanite, reduces the decomposition expansion, and increases the shrinkage [28].

3.5. Differential Thermal Analysis (DTA). The thermal inspection of mixtures by differential thermal analysis (DTA) was carried out in inert atmosphere in the range of room temperature to $1600^{\circ} \mathrm{C}$ at a heating rate of $1^{\circ} \mathrm{C} / \mathrm{min}$ until $950^{\circ} \mathrm{C}$, above $950^{\circ} \mathrm{C}$, and the heating rate was increased to $10^{\circ} \mathrm{C} / \mathrm{min}$ to avoid much further oxidation [29]. In accordance with $\mathrm{Yu}$ [30], the mullite formation reaction is generally exothermic when oxide powders serve as the reactants; 


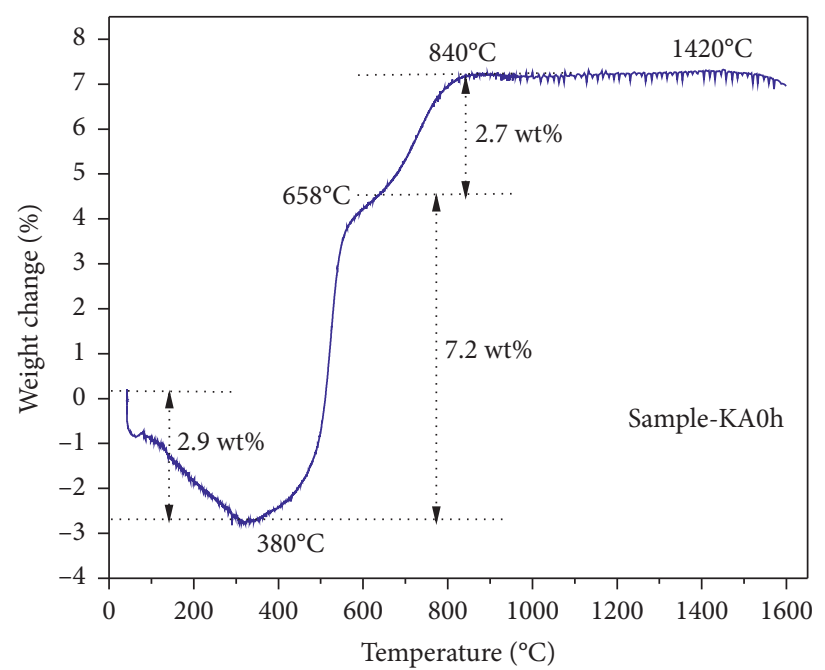

(a)

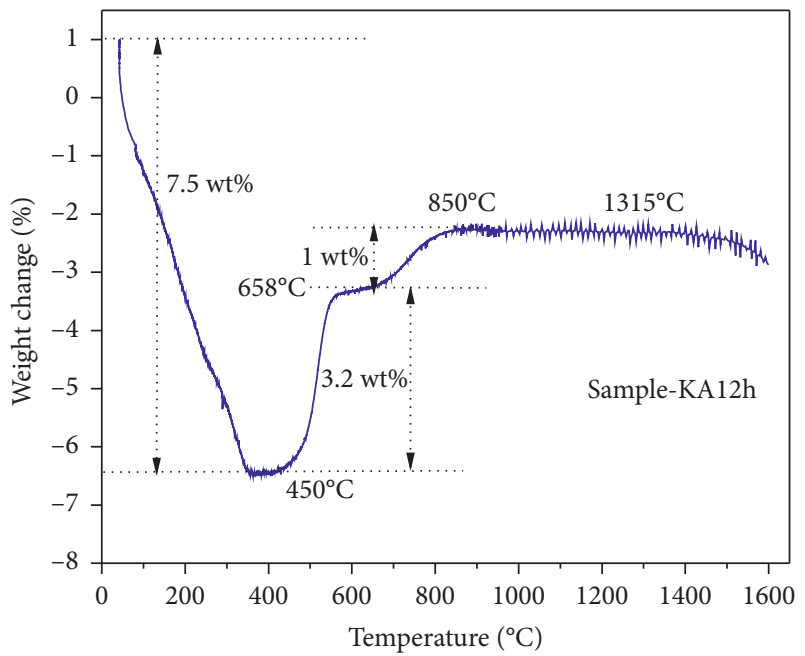

(b)

FIGURE 7: Thermogravimetric behavior of samples KA0h (a) and KA12 h (b).

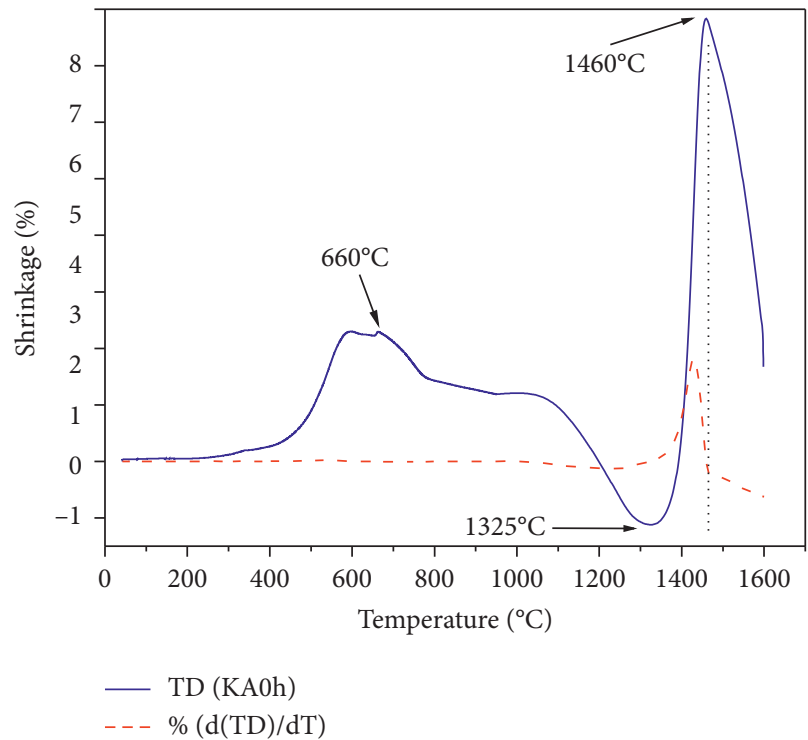

(a)

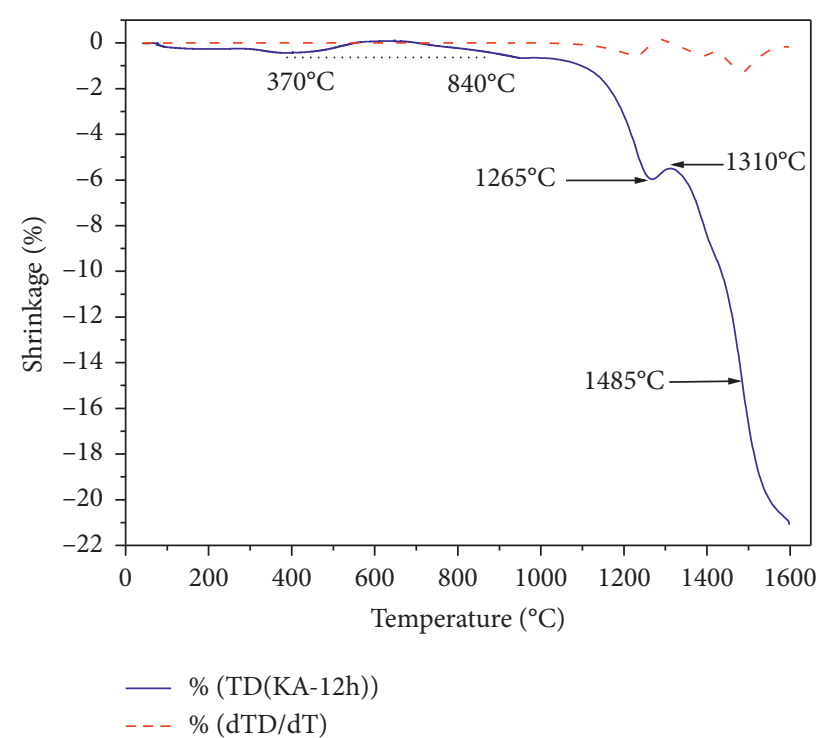

(b)

FIgURE 8: Thermodilatometric behavior of the mixture unmilled KA0 h (a) and attrition-milled mixture KA12 h (b).

agreed with this, several exothermic peaks could be observed (Figure 9(a)). Peak at $325^{\circ} \mathrm{C}$ was associated with the evaporation of organic species that were absorbed during milling, an exothermic peak was observed that has a maximum at $571^{\circ} \mathrm{C}$ corresponding to the oxidation of aluminum in solid state, and at $659^{\circ} \mathrm{C}$, a small endothermic peak due to the fusion of aluminum was identified. In the range of $720-740^{\circ} \mathrm{C}$, a fairly wide and low-intensity endothermic peak was observed, which corresponds to the oxidation of aluminum in liquid state. At $965^{\circ} \mathrm{C}$, a disturbance of the curve caused by the change in heating rate from $1^{\circ} \mathrm{C} / \mathrm{min}$ to $10^{\circ} \mathrm{C} / \mathrm{min}$ is shown, so it is not a thermal event associated with changes in the sample. At $1286^{\circ} \mathrm{C}$, an endothermic event started, which finished at $1460^{\circ} \mathrm{C}$, and the above one coincides reasonably well with the starting and ending temperatures of the decomposition of kyanite, which was observed in the dilatometry curve (Figure $8(\mathrm{a})$ ). At $1508^{\circ} \mathrm{C}$, a small exothermic peak that could correspond to the reaction between $\alpha-\mathrm{Al}_{2} \mathrm{O}_{3}$, which comes from the oxidation of aluminum, and the silica expelled by the decomposition of kyanite to form secondary mullite. In Figure 9(b) (sample $\mathrm{KA} 12 \mathrm{~h}$ ), basically the same endothermic peaks $\leq 965^{\circ} \mathrm{C}$ corresponding to sample KA0 $\mathrm{h}$ are shown. The main difference corresponds to the temperatures of initiation and termination of the decomposition of kyanite, and the transformation temperature of the secondary mullite and these thermal events correspond to the endothermic peaks located at 1215,1330 , and $1400^{\circ} \mathrm{C}$, respectively. In 


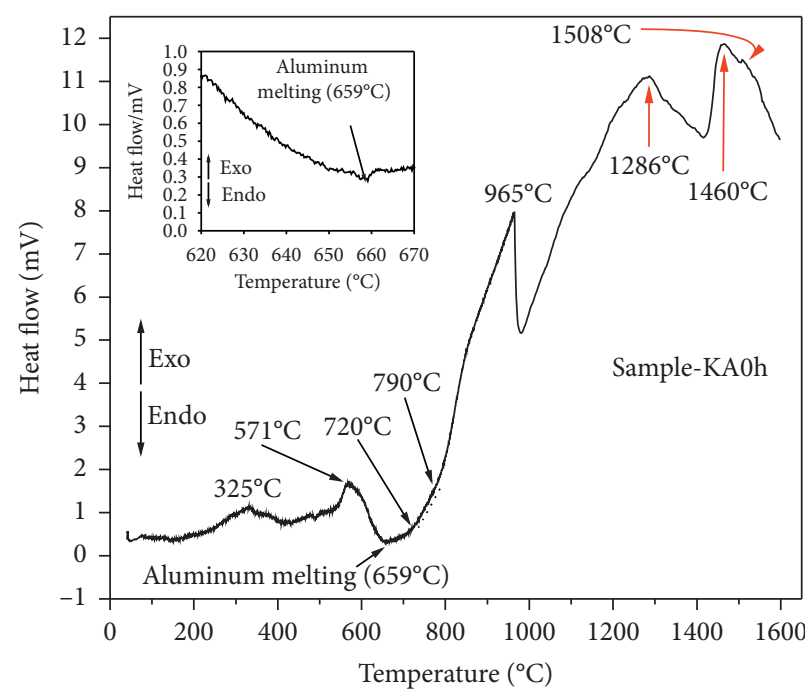

(a)

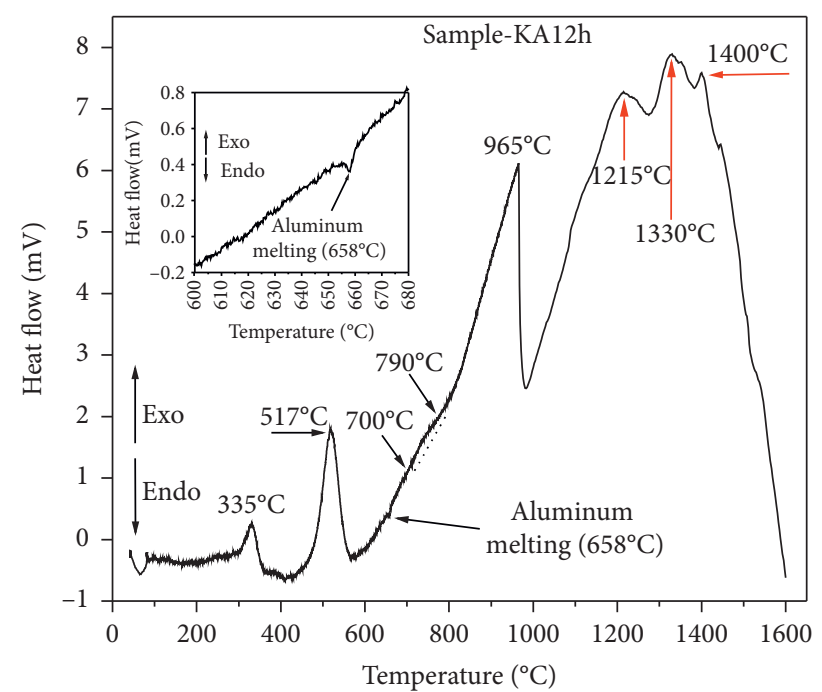

(b)

Figure 9: DTA curves of the kyanite-aluminum mixtures unmilled (a) and $12 \mathrm{~h}$ milled (b).

Figures 9(a) and 9(b), can be noticed an insert where can be seen an enlargement of the endothermic peak corresponding to the fusion of aluminum.

3.6. Bulk Density and Open Porosity. Variations of bulk density and open porosity of mullite samples at different milling time are depicted in Figures 10(a) and 10(b), respectively; in Figure 10(a), it is observed that at temperatures of 1100 and $1200^{\circ} \mathrm{C}$, there is a very small variation, and these values decreased when reaching the temperature of $1300^{\circ} \mathrm{C}$, due to the expansion produced during the decomposition reaction of kyanite. From $1400^{\circ} \mathrm{C}$, the increase in density is restarted for all samples except for the unground sample (KA0h), which does not densify due to the particle size $(400 \mu \mathrm{m})$ and the strong expansion $(\approx 18 \%)$ due to decomposition of kyanite causing cracking [9]. Upon reaching $1500^{\circ} \mathrm{C}$, the density continued to increase, and at $1600^{\circ} \mathrm{C}$, the maximum density was reached for the sample ground for $12 \mathrm{~h}$ (KA12 h) of $3.04 \mathrm{Kg} \cdot \mathrm{m}^{-3}$, approximately $96.2 \%$ of the density theoretical of mullite $\left(3.16 \mathrm{Kg} \cdot \mathrm{m}^{-3}\right)$. It has been shown that the decomposition of kyanite starts at surface sites. From this perspective, the decrease in particle size activates the thermal decomposition of the surface that already has an increase in surface area and the amount of microcracks. In this way, the concentration of nucleation sites increases where decomposition can start. Many of the main factors that have a marked influence on the sinterability of ceramic materials are related to the characteristics of the compacted powder: the heating conditions and the $\mathrm{Al}_{2} \mathrm{O}_{3} / \mathrm{SiO}_{2}$ ratio of the precursor materials. The effect of the agglomeration of dust particles on the sintering of mullite has also been evaluated [4]. The density reached will depend on the size and packing of the agglomerates, and breaking them will produce additional surface areas and smaller particle sizes. The presence of higher contents of alumina and $\mathrm{SiC}$ with low melting silicate phases increase the bulk density and consequently decrease the apparent porosity of samples [31]. Regarding the results of open porosity (Figure 10(b)), it was observed that in the KA0 h sample, the open porosity ranges from $20.7 \%$ at $1100^{\circ} \mathrm{C}$ until reaching a maximum of $26.20 \%$ at $1600^{\circ} \mathrm{C}$, in the temperature range of 1500 to $1600^{\circ} \mathrm{C}$, a decrease in open porosity was observed, that is, an increase in density, and this is related to the contraction seen in the dilatometry curves (Figure 8) since in this temperature interval, a stage of shrinkage causes an increase in density. Samples KA0.5 h, KA3 h, KA6 h, and KA12 h show a similar behavior; they show a decrease in porosity in the range of $1100-1500^{\circ} \mathrm{C}$, remaining constant up to $1600^{\circ} \mathrm{C}$.

3.7. Microstructure. The microstructures obtained after heating at $1600^{\circ} \mathrm{C}$ of the samples milled at different times are observed in Figure 11, and the sample prepared with the unmilled kyanite KA0 h (Figure 11(a)) showed a great cracking, which is attributed to the great expansion of the decomposition [9]. In Figures 11(b)-11(e), the microstructures for the samples KA0.5 h, KA3 h, KA6 h, and $\mathrm{KA} 12 \mathrm{~h}$, respectively, are shown. In these figures, elongated mullite grains were found, surrounded by a dark phase [32]. It is well known that mullite grains with these characteristics grow when they are immersed in a vitreous phase. In this microstructure, it is clearly observed that milling improves the reactivity of kyanite with alumina. During heating, aluminum oxidizes and deposits on the surface of the kyanite particles, and when this species decomposes, primary mullite is formed and silica precipitates, as shown by the XRD patterns of these samples; the silica is expelled to the surface and comes into contact with the alumina grains reacting to form secondary mullite. In the samples prepared in this work, there was an alumina deficiency (see Table 1), possibly because during the milling, an amount of aluminum was lost that was 


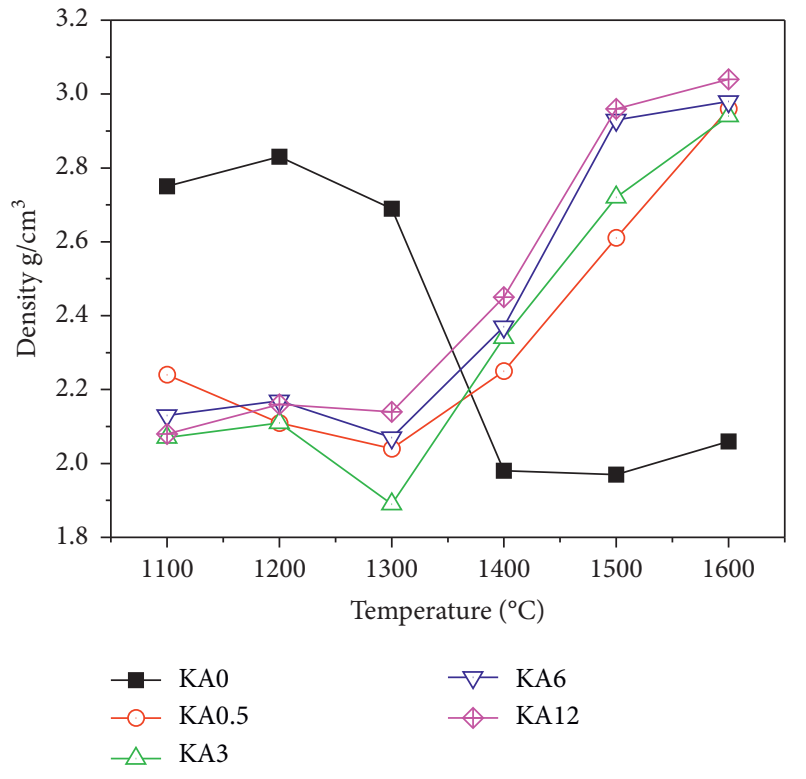

(a)
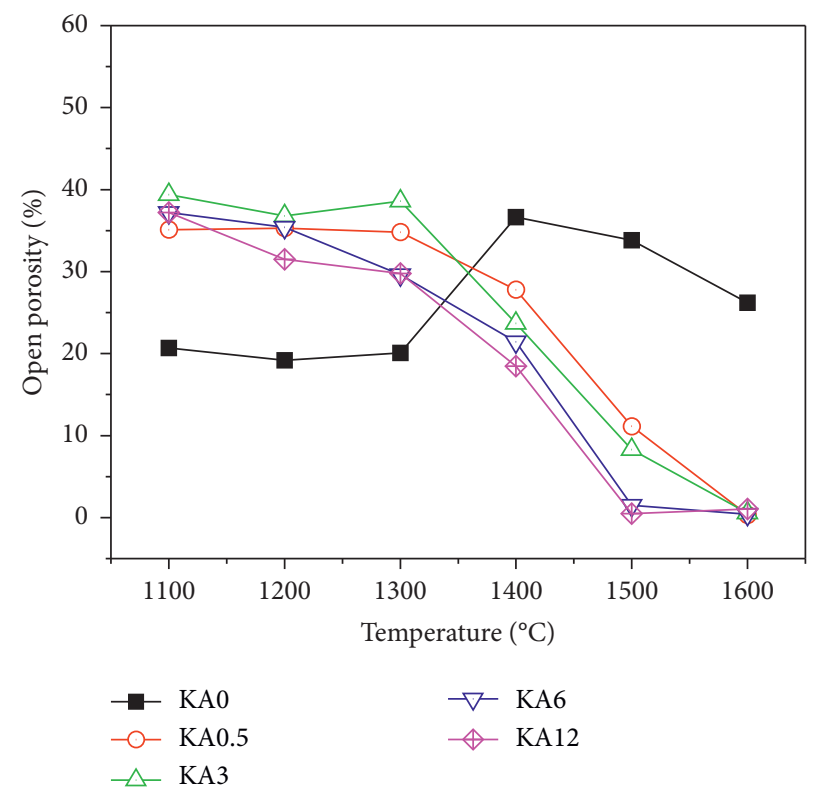

(b)

Figure 10: Density (a) and open porosity (b) of samples as function of sintering temperature and ball milling time.

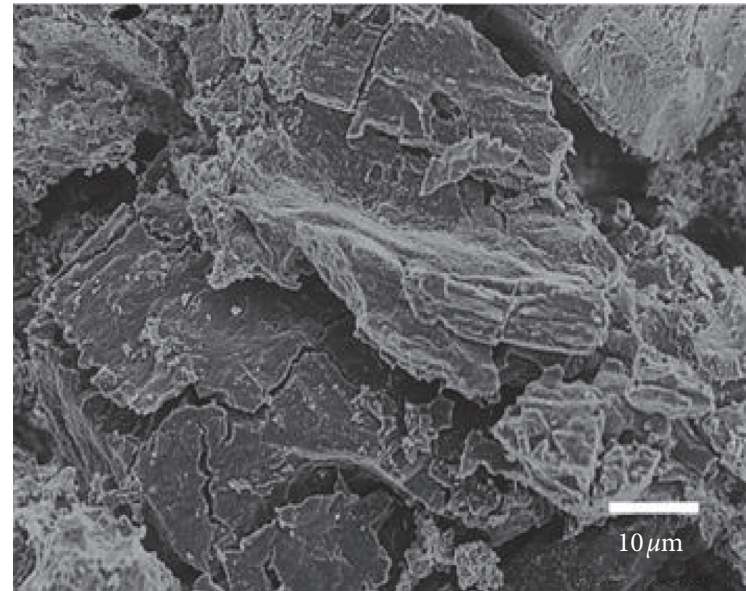

(a)

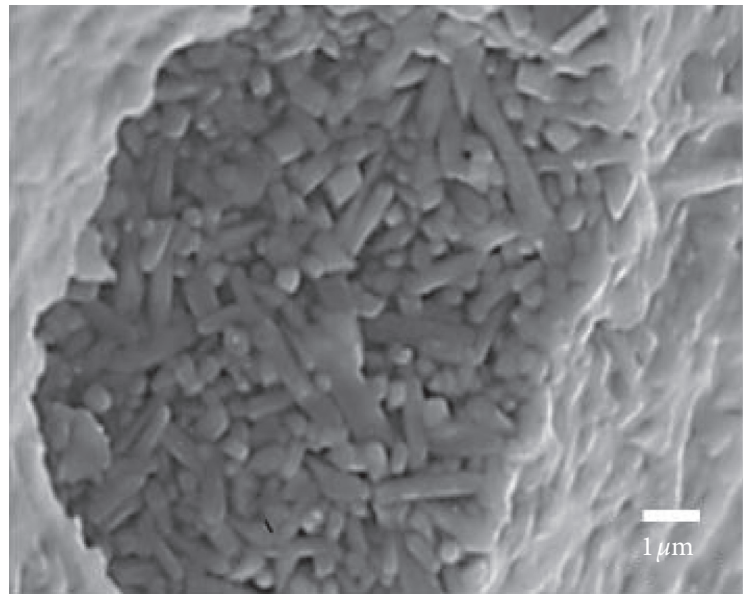

(c)

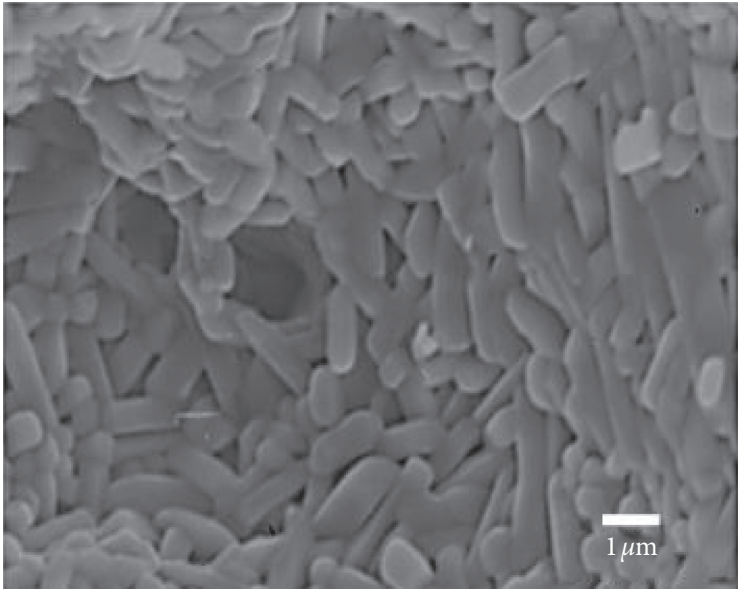

(b)

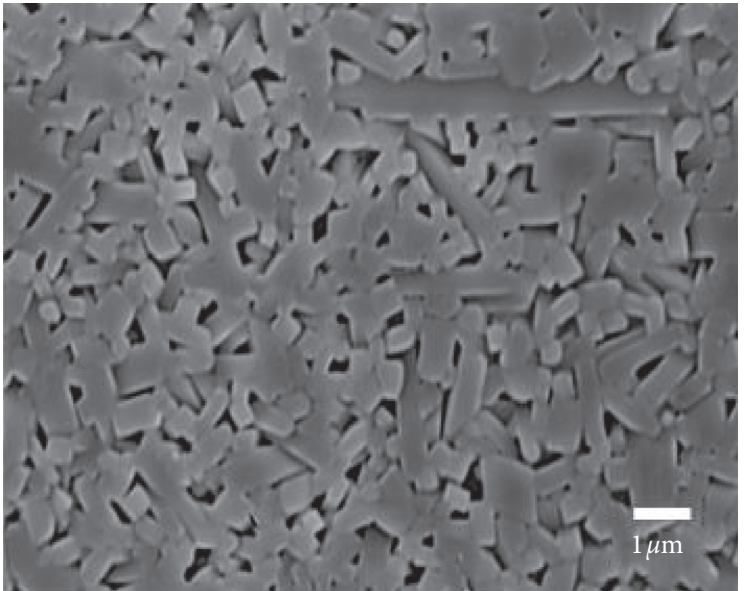

(d)

Figure 11: Continued. 


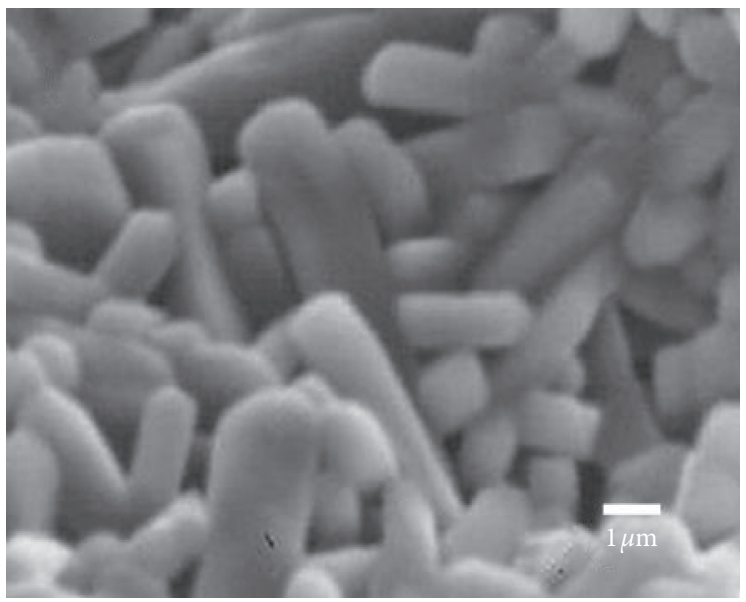

(e)

Figure 11: Scanning electron micrographs of $3: 2$ mullite. Specimen was sintered at $1600^{\circ} \mathrm{C}$, cold uniaxially pressed, and thermally etched: (a) KA0 h, (b) KA0.5 h, (c) KA3 h, (d) KA6 h, and (e) KA12 h.

adhered to the walls of the mill and to the grinding elements. Because of this, the samples had an excess of liquid phase in which the mullite grains grow, as observed in the microstructures; the liquid phase can also form from the eutectic reactions between alumina and silica by impurities existed in kyanite. In unmilled mixtures, this vitreous phase is not expelled to the surface of the transformed grains, but it is trapped inside it. As Awaad et al. [33] pointed out, mullite formation is independent on the $\mathrm{Al}_{2} \mathrm{O}_{3} / \mathrm{SiO}_{2}$ ratio, but greatly dependent on the type and amount of glassy phase present. Therefore, the mullitization reaction is slower and cannot be completed. As the particle size decreases, denser and finer microstructures are obtained, with less open porosity and more homogeneous which is promoted by grinding.

\section{Conclusions}

(i) The present study shows that mullite can be obtained by reaction sintering of kyanite and aluminum metal powders.

(ii) The decomposition reaction temperatures for kyanite and aluminum powders mixtures were lower relative to unground kyanite. Therefore, we have that the transformation and growth of mullite is faster, deducing that this process depends on the particle size and the specific surface area.

(iii) The reduction of the particle size by grinding influences the thermal decomposition of the kyanite, the expansion due to this transformation, and the secondary mullite formation reaction and increases the shrinkage.

(iv) Milling significantly increases the reactivity of the kyanite. The milled kyanite decomposes faster and at lower temperatures than coarse kyanite.

(v) The reaction between the silica expelled from the kyanite and alumina that forms in situ starts at $\sim 1400^{\circ} \mathrm{C}$. This reaction occurs faster for mixtures that contain finer kyanite.

(vi) A milling time of $6 \mathrm{~h}$ is appropriate for obtaining micron size grains of mullite.

\section{Data Availability}

The data used to support the findings of the study are available from the corresponding author upon request.

\section{Conflicts of Interest}

The authors declare that there are no conflicts of interest regarding the publication of this paper.

\section{Acknowledgments}

The authors are grateful to CONACYT for the financial support to carry out this project.

\section{References}

[1] N. M. Rendtorff, S. Gómez, M. R. Gauna, M. S. Conconi, G. Suarez, and E. F. Aglietti, "Dense mullite-zirconia-zirconium titanate ceramic composites by reaction sintering," Ceramics International, vol. 42, no. 1, pp. 1563-1572, 2016.

[2] H. Ashrafi, R. Emadi, and R. Zamani Foroushani, "Synthesis and characterization of mullite-zirconia nanostructured composite by combined mechanical activation and reaction sintering," Advanced Powder Technology, vol. 26, no. 5, pp. 1452-1457, 2015.

[3] D. Liu, K. Gui, J. Long, Y. Zhao, W. Han, and G. Wang, "Lowtemperature densification and mechanical properties of monolithic mullite ceramic," Ceramics International, vol. 46, no. 8, pp. 12329-12334, 2020.

[4] H. Schneider, J. Schreuer, and B. Hildmann, "Structure and properties of mullite-A review," Journal of the European Ceramic Society, vol. 28, no. 2, pp. 329-344, 2008.

[5] H. Schneider, K. Okada, and J. A. Pask, Mullite and Mullite Ceramics, John Wiley \& Sons, Hoboken, NJ, USA, 1994. 
[6] C. G. Smith, "An introduction to the scottish mineral geological conservation review sites," Proceedings of the Geologists' Association, vol. 128, pp. 1-14, 2017.

[7] J. Shackelford and R. Doremus, Ceramic and Glass Materials, Structure, Properties and Processing, Springer, New York, NY, USA, 2008.

[8] T. Manfredini and M. Hanuskova, "Natural raw materials in traditional ceramic manufacturing," Journal of the University of Chemical Technology and Metallurgy, vol. 47, pp. 465-470, 2012.

[9] H. Schneider and A. Majdič, "Kinetics of the thermal decomposition of kyanite," Ceramurgia International, vol. 6, no. 2, pp. 61-66, 1980.

[10] M. A. Sainz, F. J. Serrano, J. Bastida, and A. Caballero, "Microstructural evolution and growth of crystallite size of mullite during thermal transformation of kyanite," Journal of the European Ceramic Society, vol. 17, no. 11, pp. 1277-1284, 1997.

[11] A. Raghdi, M. Heraiz, F. Sahnoune, and N. Saheb, "Mullitezirconia composites prepared from halloysite reaction sintered with boehmite and zirconia," Applied Clay Science, vol. 146, pp. 70-80, 2017.

[12] D. Goski and W. F. Caley, "Reaction sintering of kyanite and alumina to form mullite composites," Canadian Metallurgical Quarterly, vol. 38, no. 2, pp. 119-126, 1999.

[13] F. Chargui, M. Hamidouche, H. Belhouchet, Y. Jorand, R. Doufnoune, and G. Fantozzi, "Mullite fabrication from natural kaolin and aluminium slag," Boletín de la Sociedad Española de Cerámica y Vidrio, vol. 57, no. 4, pp. 169-177, 2018.

[14] H. Guo and W. Li, "Effects of Al2O3 crystal types on morphologies, formation mechanisms of mullite and properties of porous mullite ceramics based on kyanite," Journal of the European Ceramic Society, vol. 38, no. 2, pp. 679-686, 2018.

[15] P. J. Sánchez-Soto, D. Eliche-Quesada, S. Martínez-Martínez, E. Garzón-Garzón, L. Pérez-Villarejo, and J. M. Rincón, “The effect of vitreous phase on mullite and mullite-based ceramic composites from kaolin wastes as by-products of mining, sericite clays and kaolinite," Materials Letters, vol. 223, pp. 154-158, 2018.

[16] C. Sadik, I.-E. El Amrani, and A. Albizane, "Recent advances in silica-alumina refractory: a review," Journal of Asian Ceramic Societies, vol. 2, no. 2, pp. 83-96, 2014.

[17] E. A. X. Moreno and A. N. Scian, "High purity mullite by slip casting method from calcined alumina and kaolinitic clay," Procedia Materials Science, vol. 8, pp. 245-250, 2015.

[18] N. Claussen, T. Le, and S. Wu, "Low-shrinkage reactionbonded alumina," Journal of the European Ceramic Society, vol. 5, no. 1, pp. 29-35, 1989.

[19] S. K. S. Hossain, R. Pyare, and P. K. Roy, "Synthesis of in-situ mullite foam using waste rice husk ash derived sol by slipcasting route," Ceramics International, vol. 46, no. 8, pp. 10871-10878, 2020.

[20] W. Wang, W. Chen, and H. Liu, "Recycling of waste red mud for fabrication of $\mathrm{SiC} /$ mullite composite porous ceramics," Ceramics International, vol. 45, no. 8, pp. 9852-9857, 2019.

[21] X. Deng, Y. Wu, T. Wei et al., "Preparation of elongated mullite self-reinforced porous ceramics," Ceramics International, vol. 44, no. 7, pp. 7500-7508, 2018.

[22] J. Fang, B. Yan, and T. Deng, "Fast transformation of andalusite into mullite by addition of yttria," Boletín de la Sociedad Española de Cerámica y Vidrio, vol. 58, no. 4, pp. 142-150, 2019.
[23] M. A. Trunov, M. Schoenitz, and E. L. Dreizin, "Effect of polymorphic phase transformations in alumina layer on ignition of aluminium particles," Combustion Theory and Modelling, vol. 10, no. 4, pp. 603-623, 2006.

[24] T. Sahraoui, H. Belhouchet, M. Heraiz, N. Brihi, and A. Guermat, "The effects of mechanical activation on the sintering of mullite produced from kaolin and aluminum powder," Ceramics International, vol. 42, no. 10, pp. 12185-12193, 2016.

[25] R. Sule and I. Sigalas, "Effect of temperature on mullite synthesis from attrition-milled pyrophyllite and $\alpha$-alumina by spark plasma sintering," Applied Clay Science, vol. 162, pp. 288-296, 2018.

[26] T. Ebadzadeh, "Effect of mechanical activation and microwave heating on synthesis and sintering of nano-structured mullite," Journal of Alloys and Compounds, vol. 489, no. 1, pp. 125-129, 2010.

[27] R. M. Khattab, A. M. El-Rafei, and M. F. Zawrah, "In situ formation of sintered cordierite-mullite nano-micro composites by utilizing of waste silica fume," Materials Research Bulletin, vol. 47, no. 9, pp. 2662-2667, 2012.

[28] H. Schneider and S. Komarmeni, Mullite, Wiley VCH, Weinheim, Germany, 2005.

[29] N. Claussen, S. Wu, and D. Holz, "Reaction bonding of aluminum oxide (RBAO) composites: processing, reaction mechanisms and properties," Journal of the European Ceramic Society, vol. 14, no. 2, pp. 97-109, 1994.

[30] P.-C. Yu, Y.-W. Tsai, F.-S. Yen, W.-P. Yang, and C.-L. Huang, "Thermal characteristic difference between $\alpha$-Al2O3 and cristobalite powders during mullite synthesis induced by size reduction," Journal of the European Ceramic Society, vol. 35, no. 2, pp. 673-680, 2015.

[31] M. F. Zawrah and M. H. Aly, "In situ formation of $\mathrm{Al}_{2} \mathrm{O}_{3}$ $\mathrm{S}_{\mathrm{i}} \mathrm{C}$-mullite from Al-matrix composites," Ceramics International, vol. 32, no. 1, pp. 21-28, 2006.

[32] M. F. Zawrah, H. A. Badr, and R. M. Khattab, "Recycling and utilization of some waste clays for production of sintered ceramic bodies," Silicon, vol. 12, no. 5, pp. 1035-1042, 2020.

[33] M. Awaad, M. F. Zawrah, and N. M. Khalil, "In situ formation of zirconia-alumina-spinel-mullite ceramic composites," Ceramics International, vol. 34, no. 2, pp. 429-434, 2008. 